Мр Ненад Р. Кебара

ИП Лира Крагујевац

lirakragujevac@gmail.com
821.163.41.09 Кочић П. https://doi.org/10.18485/ai_kocic.2017.ch15

\title{
ГЕНЕАЛОГИЈА И ФУНКЦИЈА ПАРЕМИЈЕ У КОЧИЋЕВОМ КЬИЖЕВНОМ СВЕТУ
}

Најкраће облике књижевног усменог израза: іоворне изразе, изреке и йословище, које наука о књижевности различито назива, посматрамо као јединствени принцип стварања који важи за йаремију. Немогућност општеважеће дефиниције видимо у двострукој природи паремије, састављене од језичког израза и догађаја који је оваплоћује. Одакле потиче и како се тај нарочити тип фолклорног мишљења одражава на веродостојност књижевног света, када је главно својство његовог стварања, у овом раду испитујемо на примерима књижевног дела Петра Кочића. Закључујемо да постоји својеобразни принцип паремије и да се његово деловање може препознати у многим елементима књижевне структуре обимнијих дела у чијем стварању учествује.

Кључне речи: паремија, усмена књижевност, књижевни свет, структура, стилизација, фигуре негације.

\section{Онтогенетски увод у термине}

Вукова реформа језика није само пука филолошка стандардизација писмености, колико је важан његов системски граматички рад изражен у Писменици и Рјечнику, толико је значајан корпус народне књижевности који је он сакупио и уградио у духовни темељ српскога 
народа. Код већине истраживача прећутно је установљена хијерархија по којој се на врху налазе четири књиге Срйских нароgних йјесама, потом Срйске нароgне йрийовјейке и тек на концу Срйске нарояне йословице и gруіе различне као оне у обичај узейе ријечи (Караџић 1975a). Не спорећи значај двама првим врстама народног књижевног израза, намера нам је да донекле расветлимо општеприсутне недоумице око термина, чиме ћемо учинити оперативнијим наш рад на примерима Кочићевог приповедања. И пре Вука постојале су у нашој култури сакупљене збирке пословица и других сродних врста (3. Орфелин, J. Мушкатировић, Д. Обрадовић), али је он са највећом пажњом приступио њима дајући само наизглед неуједначена и прилично разноврсна објашњења за појединачне примере које је уврстио у своју збирку. Време ће показати да ни до данас лингвистика и наука о књижевности нису успеле да пронађу општеважећи критеријум по којем би неупитно дефинисали, попут свих осталих, ову књижевну врсту. Тако их домаћа и страна наука до наших дана, опредељујући се према сопственим уверењима или потребама, назива мноштвом термина који се преклапају и делимично дистингвирају, углавном обраћајући пажњу на краткоћу форме тих сублимних израза, њихове текстуалне, композиционе и структурне особине, као и функцију, а занемарујући унутрашњи волуминозни простор догађаја које могу обухватити. Стога Вукове нароgне ӣословице и gруїе различне као оне у обичај узете ријечи у разним научним прилазима можемо да пронађемо у појмовима: іоворни изрази, изреке, сенйени(иј)е, афоризми, иоословице и йаремије или чак у описним терминима крайке и јеgносйавне форме. ${ }^{1}$ Поред тога што ни савремена наука није нашла заједнички критеријум који би омогућио дефинисање ових

1 Погледати у Јовановић 2006: 13-38. 
веома старих израза, створила се и терминолошка збрка која настоји све наведене називе истовремено да разликује и подразумева њихову замало истоветност. (Латковић 1987; Живковић 1992; Милошевић-Ђорђевић 2006; Јовановић 2006; Пешић, Милошевић-Ђорђевић 2011).

Та ситуација истог а различног нарочито се јасно опажа код дефинисања краћих облика, док у примерима који могу бити основа сложенијим приповедним врстама или су њихов, сажетак, поента, термин добија и одређену књижевно-историјску пројекцију. Тако укратко може да се каже да су изреке стилизовани, фигуративно оформљени језички искази експресивне вредности, лако применљиви у разним реченичним склоповима, при чему могу бити скраћиване или прошириване. Код изреке је мање изражена склоност ка уопштавању а више ка конкретној ситуацији. Ваљан пример са свим овим особинама је изрека „Иш, не праши!“ (Караџић 1975a: 106) и њен елиптични еквивалент „Иш!“, за који се може рећи и да је најкраћа реченица у српскоме језику. То је пример у којем се веома јасно оцртава колико је у разумевање његовог значења укључен ванјезички: друштвени, етички, фолклорни и психички ниво, што упућује на питање да ли је језичку творевину која је у тако значајној мери обележена и условљена ванјезичким елементима уопште могуће дефинисати само лингвистичким мерилима?! Готово да се изрека не разликује од онога што се именује іоворним изразом, који су на нивоу синтагме или реченице, стилизоване, са својством семантичке самосталности и када су граматички несамостални будући да су најчешће неодвојиви од културног простора у којем су настали. Веома доприносе сликовитости, као и сугестивности казивања као одређени помоћни ауторитет говорника унутар изреченог. Када је изражена та црта, наука је описује као самониклу и у њу убраја: благослове, клетве, заклетве и поређења (Пешић, Милошевић - Ђорђевић 2011: 59). 
Са йословицама, и у историјском и у жанровском смислу, разлике добијају нешто јасније црте, иако је и овде реч о језгровитом и фигуративном исказу мисли. Од Вуковог објашњења до данашњег разумевања ових провербијалних израза пређен је дуг пут, но у овој краткој књижевној врсти готово се ништа није променило, тако да можемо да говоримо о својеврсној петрификованој форми, унутар које се стално остварују нови садржаји. Њено ослањање на фигуративни говор показује још и већу склоност ка метафори неголи код претходно поменутих - говорних израза и изрека. Српско име пословица води порекло из руског лексичког извора слов(-о), што у преводу на наш језик означава реч, али у самом конкретном примеру претпоставља причу, односно, нарочито излагање вештог говорника у посебним приликама, које подразумева традиционалне облике беседништва када се исказују посебне поруке настале на искуству вековног трајања генерација, применљиве на појединачне ситуације, тј. догађаје. Догађај на који се односи пресудно је значајан за исправно поимање пословице, зато што са стајалишта формалне логике и етике, оне не морају да буду исправне, према томе, догађај за који се вежу је друга половина њиховог дихотомијског садржаја. Стваралачки су обликоване, са приметним уделом индивидуалног књижевног талента, представљају особите књижевне конструкције на нивоу композиције и стила. Веома лако су замисливе као згуснуте мисаоно-вербалне поенте других, ширих од њих облика, народног приповедања. Приповедање је овде условно будући да су оне највидљивије у народном поетском изразу. Међутим, у народној и у књижевној традицији присутан је и обрнут процес где је пословица основа на којој настају сложенији облици приповедања. „Хоћемо нпр. рећи да, као што је могуће сажимање приповедног текста у пословичку форму, исто је тако могућ развој пословице у приповедни текст.“ 
(Јовановић 2006: 33). Њено присуство у облицима који се развијају ширећи је није пуко, фактичко, оно може бити и имплицитно, а није ни једнозначно, већ је усмерено

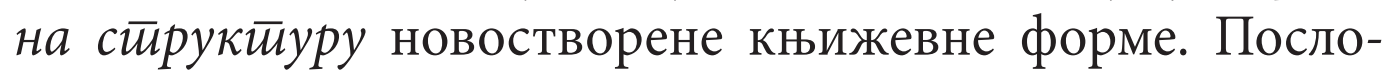
вице су веома стари облици књижевног израза, могу се пратити по сачуваним збиркама дубље од антике, безмало до индоевропских извора, нарочито су познате у европским књижевностима оне из времена хуманизма из којих се развио приповедачки жанр йримера. Та древност за наш приступ Кочићевом приповедању благотворан је по томе што се у њима могу осетити „трагови митолошког доживљаја језика, кад се реч није одвајала од ствари и свако деловање на реч и веза између речи осећали се као деловање на саму ствар и реална веза између самих ствари.“ (Петковић 1975: 197-198). Даље се наводи да су управо кратке, тзв. маргиналне форме у народној књижевности прве приступиле формализацији садржаја, чиме је дошло до канонизащије различитих поступака приликом реализације језичких конструкција, а то је омогућавало њихове употребне могућности у сложенијим облицима (исто). Управо у томе увиђамо функционални потенцијал који поседује метафора, што резултује да је њено присуство осетније од нешто мање видљивих - метонимије, антитезе и др.

Наше свеобухватно терминолошко решење је да је то одуховљено искуство оваплоћено у сублимном књижевнојезичком облику. У тој описној дефиницији истакнуто је оно што је општеважеће за све мање врсте и битно за рад о Кочићевом делу, а то је својеврстан йаремијски $\bar{u}$ ринций по којем оне настају, а изостављене њихове типичне језичке нијансе, морфолошке и синтаксичке природе, које у овом случају нису пресудне. Зато смо се определили за термин йаремије како би било обухваћено оно што је онтолошки суштаствено за све врсте језгровитих усмених књижевних израза, као и у Кочићевом књи- 
жевном делу. При томе смо апстраховали књишке врсте попут сентенци(ја), мисли, афоризама и апофтегми на које би се, такође, могао односити тако дефинисани стваралачки прнцип. Исто тако упућује на то да са може посматрати као заједничко композиционо-структурно-семантичко устројство којим су организовани нарочити облици старијих књижевних израза, попут парамитија, паренесиса, паримија... (Живковић 1985: 568-569).

Други део наслова рада односи се на простор у којем се остварује књижевна функција пословица, а то је Кочићев књижевни свет, њихова улога у структури и веродостој-

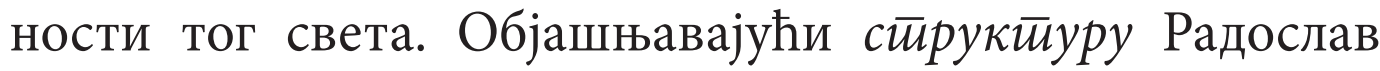
Катичић наводи да „sadržaj književne postave nema neposredne veze sa zbiljskim svijetom, nego nam dočarava svoj svijet. Prema tome specifična struktura književnog jezika jeste 'struktura jezikom dočarana svijeta' koji je autonoman, ne zavisi od zbiljskog i postoji kao u se zatvorena cjelina." (Катичић 1992: 116). Ако бисмо ове констатације хрватског научника узели као безусловне, показало би се да паремије, у значајном броју, нису аутономне од збиљског, реалног света будући да аутономним разумевањем књижевне структуре оне не оправдавају увек функцију моралне парадигме која им је иначе инхерентна. Исто то о Катичићевим ставовима можемо закључити на основу Кочићевог књижевног света. У паремијском књижевном руху у различитим делима његовог књижевног опуса појављују се непротивречни топоси и потпуно исти протагонисти књижевне радње у неизмењеним животним улогама. Осим града и села, друштвене и социјалне средина, нпр. у причама о Симеуну Ђаку, у драми Јазаваи, ūpeg cygoм и/или у причи Ту $\delta a$, улога Давида Штрпца, појединачне текстове - приповетке и драму доводи у књижевну коегзистенцију којом се њихови сегментирани књижевни простори уклапају у свеобухватно пространство књижевног света Петра Кочића. Дакле, у оквирима 
свих његових књижевних наслова аутономност појединих топоса, као и разноврсно структурирање појединих књижевних текстова, споредни су у односу на заједничарење личносних одлика у приповедним и драмским целинама, а томе значајно доприноси, пре свега, установљење књижевног света на координатама израженим у паремијама. Књижевност се остварује у простору неког усвојеног система знакова, како то каже Топоров, или коgова, у терминологији Лотмана, који представљају преведено живо искуство времена и пространства у којем се збивају. Бахтин ће на сличним особеностима књижевног текста да установи појам хронойой, који је итекако зависан од места и времена, тј. реалне судбине учесника у књижевном догађају. Свака култура и национална књижевност на тај начин представљају једну особиту врсту читљивог текста. С тим је нераскидиво повезана симболизација књижевног простора чије је порекло у духовној сфери, како би рекао Достојевски у живом живойу, будући да појединац и народи живе једнако и у духовној стварности као и у материјално-биолошкој реалности. Паремија као сублимни носилац искуства у књижевност улази са одређеним вредностима, које је већ пре реинтерпретације у књижевним врстама већег обима задобила у свакодневној утилитарној употреби, која ипак никада није само утилитарна. Тиме у писану књижевност уноси и одуховљено присуство објектног света, заједно са његовим афективним доживљајем, а она, иако јесте књижевна структура, тада није лишена спољашњег света. То доказује и белоданост да све на лествици бића, па и сама књижевност, усмена или књишка, може бити захваћено поступком одуховљења у некој новој књижевној преради. Присуство паремијског супстрата у књижевном стварању, пре свих код Петра Кочића, суштаственије је од самог обележја стила, упркос томе што је и ту јако изражено. 


\section{Порекло Кочићевих паремија}

У остварењу књижевног света Кочић се користи паремијом не мање од Његоша, а колико је то чинио најзначајнији српски песник, најбоље говори чињеница да се код појединих изучавалаца појављује и термин юеїошизми. Њихове ликове чини сроднима склоност да сваки шири исказ зачине изреком а закључивање поентирају у високом поетском говору. Раздваја их то што код великог песника постоји тенденција новостворених песничких мисли са особинама паремије, док приповедач истовремено користи постојеће провербијалне изразе из народног стваралаштва, али и са̂м твори облике на народну. Међутим, граница је сасвим порозна, колико је нешто народно или ауторско у оформљеном паремијском облику готово је ирелевантно јер је генеалошки увек у културном типу у којем се јавља. Вук је и са̂м посведочио да је захваљујући Његошу чуо и записао многобројне народне пословице и изразе, те да није било тог сусрета два великана, сигурно је да би штошта било заувек изгубљено. Несумњиво је да је од Његоша чуо нераздељено оне облике који су у целини изворни, али и друге које је у већој или мањој мери песник преобразио или сасвим инокосно сачинио, као и то да га је Владика упутио и на друге узорне казиваче у свом окружењу (Латковић 1987: 216).

Састав Вукове књиге најбоље сведочи колико је богатство са једне стране сачувао захваљујући плодоносним сусретима са одређеним крајевима и појединцима и истовремено колико је тога испуштено само због тога што нису били могући сусрети са другим областима српског простора и појединцима који би у том послу били од користи. „Идући Вуковим трагом, наилазимо на пословице које је он слушао на толиким тачкама наше земље и у толиким њеним срединама: 'у Маџарској и по 
варошима (3) или само у Маџарској (3), у Сријему (4), у Србији и Босни (1), у Босни и Херцеговини (1), у Херцеговини (5), у Херцеговини и по околини (2), у Приморју (14), у Дубровнику (48), у Боци (6), у Котору (28), у Рисну (18), у Перасту (1), у Прчњу и у Столиву (1), у Бару (1), у Боци и у Црној Гори (2), у Црној Гори и у Приморју (4), у Црној Гори (126), у Херцеговини и у Црној Гори (5) у Паштровићима (1), у Паштровићима и у Цр(м)ници (1), у Кучима (1)’ и другде.“ (Јовановић 2006: 17). По ознакама у заградама види се да је сакупљач одређене облике слушао и записивао у разним крајевима, а знајући да највећем броју, поглавито говорних израза и изрека није ни записао место нити објашњење, што претпоставља да их је чуо на многим местима, може да се изведе поуздан закључак да су оне постојале на разним странама а у истој духовној стварности, те да се не могу ексклузивно сматрати обележјем неког микропростора. У најужем могу се, у одређеним случајевима, одредити етно-психолошким особеностима које се срећу у српском народу, по чему их је Јелена Јовановић, темељећи систематизацију на психолошким типовима које је дао Јован Цвијић, сврстала у четири подтипа: guнарски, иентирални, ӣриморски и рајински (Јанковић 2006: 283-286).

Упоредни однос паремијских садржаја и облика у Кочићевом књижевном делу према народном усменом благу лакше је установити неголи у случајевима стваралаца који су настали у оним деловима српске књижевне традиције до које није доспео сакупљачки рад Вука Стефановића и других поузданих фолклориста. Присуство паремијских примера у приповедачком делу Петра Кочића проналазимо у потпуно неизмењеној форми у односу на Вукову књигу српских народних пословица, затим са незнатним одузимањем или додавањем несамосталних врста речи, раздвајањем непаремијским садржајем на делове да би био уметнут пишчев текст и сл. 
Мноштво говорних израза, најчешће поздрава, клетви, заклетви и других, код Кочића датих измењеним али сродним лексичким материјалом, могуће је претпоставити иза одређених примера у Вуковој књизи. Упркос лексичким разликама они се могу ставити у једнаковрсну напоредност, а по стваралачком принципу на семантичком, синтаксичком, фонолошком и семантичком нивоу ни у чему се не двоје од оних које су код Кочића. И када су лексички исте и када је језичка супстанца разноврсна делови су истог духовног простора. Несумњиво је да се Петар Кочић могао послужити фолклористичким радом Вука и других сакупљача усменог блага који су му претходили, али се ни у чему не препознаје да паремијски изрази које Кочић користи аутентично не припадају говорницима који се њима служе: „не буди примјењено“ (Кочић [1932]: 28; уп. Вук 1975а: 195); „слијеп код очију (исто: 31 ; уп. исто : 289); „Помоз’ Бог!“ (исто: 35 ; уп. исто: 254); „Које су те виле донијеле?“ (исто: 49; уп. исто: 35); „Што је од Бога, слађе је од меда“ (исто: 62; уп. исто: 356 ); „дрво на дрво, човјек на човјека“ (исто: 75, уп. исто: 70); „Ђе си био - ниђе. Шта си радио - ништа.“ (исто: 78. уп. исто: 77); „шјеме му се умело“ (исто: 171; уп. исто: 287); „Зец у шуми, а они приправљају ражањ“ (исто: 289; уп. исто: 90); „добар човјек, не 'валећи му вјере и закона“ (исто: 378; уп. исто: 211); „Меке му и слаткеријечи, на рану би и’ привио!“ (исто: 388; уп. исто: 191). ${ }^{2}$

Кочићеви јунаци су представници народа, било да су сељаци, ситни трговци, државни службеници или свештеници, који у свакодневном животу нерашчлањено, митски, живе свој физички, друштвени и духовни

2 „Читајући ово готово нам се учинило да слушамо ријечи Вука Караџића, који се, педесетак и више година прије Кочића, такође из Беча, обраћао својим познаницима и сарадницима молећи их да му шаљу ријечи, пословице, приче и остало, 'особито из Херцеговине и из Босне'...“ (Зуковић 2002: 243). 
живот. У међусобном обраћању и комуникацији они не би ни били у стању да функционишу без паремијских облика, како на вербалном тако ни на мисаоном нивоу. Присуство пословица, изрека и говорних израза у њиховом мишљењу и изражавању књижевни свет чини уметнички веродостојним - мисаоно, говорно и реални догађај готово је немогуће одвојити, те се у неким облицима имена која се уобичајено и препознатљиво појављују у паремији замењују онима која су уплетена у књижевну радњу, као што се и историјски, епски и религиозни контекст слободно умећу у постојеће облике. У неким случајевима пословице, изреке и говорни изрази се међусобно комбинују у један исказ, додавањем или уметањем, али са осећајем за склад као да је то одувек једна исказна целина. Исто тако, за културу којој припадају, једна особена навика еуфемистичког и хипокористичног обраћања саговорнику, независно од ситуације и садржаја говора, ушла је из српског народног карактера и усмене традиције и у Кочићев паремијски дијалог, што на експресиван начин говори о етнопсихолошким особинама учесника у књижевном догађају и о њиховој потреби за разумевањем и хармоничношћу односа. Такви облици, иако посве канонизовани, обилују афективном засићеношћу, које најчешће произилази из доживљаја gобра: „нијесу говорили 'наш најменик', већ 'наш Блаїи'“ (Кочић [1932]: 15); „рано моја, свијет је к’о свијет“ (исто: 19); „сестримим те“ (исто: 22); „да си Краљевић Марко морао би задрхтати!“ (исто: 20); „тако ти крсног имена“ (исто: 28); „На моју душу“ (исто: 29); „јер би се прије земља - Боже ме прости - преврнула“ (исто: 31-32); „Да ти је срце од камена, морао би пустити сузу њежног саучешћа.“ (исто: 33); „Да’ Бог добро!“ (исто: 35); „Душе ти, јеси се преп’о? (исто); „Не дај, Боже!“ (исто: 36); „Чес’ теби и поштење“ (исто: 44); „Најо драга, уме-ме-те нас Гра-а-ац“ ( исто: 46); „Која добра, добри 
Ђуро?“ (исто: 47); „Дао ти Бог добро, мој добри Ђуро“ (исто); „Здраво сван’о, господине?““ (исто); „он сваком: моја слатка душо!“ (исто: 72); ,алал му курдељ“ (исто: 96); „Боже да некоме издобри!“ (исто: 130); „пост вам ваш“ (исто: 143 ); „За тобом и у гору и у воду, делијо и војводо наш“ (исто: 208); „А, мајка ти стара, жито ти родило“ (исто: 298); „Ово су дјеца моја, сестре моје и браћа моја.“ (исто: 326 ); „по Богу брате“ (исто: 330); „Идеш ли, роде?“ (исто: 331); „брате си мој слатки и медено љето моје“ (исто: 339); „душо си моја драга, и дјецо и браћо моја“ (исто: 349 ); „Бог им не д’о“ (исто: 364 ); „Бог ти помог'о“ (исто: 367,368$) ;$ „туго моја“ (исто: 385 ).

Најједноставнији, сублимирани усмени облици истовремено су културно положени у општој традицији народа и у појединачном догађају који је обухваћен књижевним поступком. Културна парадигма традиционалног српског друштва у непосредно-интуитивној свести придаје нарочити значај имену, слично као и истородна руска у којој се развила и философска струја именословља, тако су у српској народној култури за узориту фамилијарност настали називи: сојковићи, ощаковићи, йлемићи, кољеновићи..., као и супротног вредносног предзнака: несоји, никоіовићи, јайковићи, бјежановићи и др. Име, лично, породично, фамилијарно, племенско, обласно или национално само по себи носилац је семантичког обележја, то је својеврсни херменеутички однос дела и целине, који је обавезујући на свим нивоима; како се такав однос може изразити скраћивањем у имену, тако је исто могуће превести фигуративно у паремију, а то открива својеврсну примарну ноуменалност кратких књижевних израза. У основи тих облика је сводљивост на једну особину, односно, једну или свега две-три лексеме којима се та особина, у синтагми или реченици, може исказати. Будући у сажетом језичком материјалу а недвосмисленог ширег значења, веома су употребљиви 
у комбинацијама са другим паремијским и непаремијским садржајима у већим конструкцијама: „к’о блентави Бошњак, да му није носа, пас’о би траву“ (исто: 27); „Знаш, из нашег си села, па би и нас могла биједа појаิти“ (исто: 32); „Опремио се, као што се један Делић опремити може“ (исто: 40); „неки је зову и Летикујом“ (исто: 41); „Шути, ћићулајкане бож’и, бленто, злогло!“ (исто: 44); А ви знате, кад Вла', што 'но веле Турци, у'вати вурсат мјере му нема!“ (исто: 95); „'Скини капу!' виче полако Јуре и пријеча очима на Тешицу. 'Није ми је ни ћаћа скид'о!' одговара мирно Тешица. (исто: 129); „па да је црни Циганин“ (исто: 192); „Е, то ти посигурно не умијем казати, јер се не мере сваком рећи: Царе Лазо, честито кољено!“ (исто: 195); Часног ми крста, не крстио се њим већ клањ’о к’о Турчин или носио шкрљак к'о трбушасти Ликота срам га и стид било Кристова лишца.“ (исто: 200); „Откад је свијета и вијека, 'ваког чојека није сунце виђело! (исто: 263); „Шта толико теслаишеш! Што си се толико диг’, нијесу на теби токе и илике Реље Кнежевића!“ (исто: 320); „Кад не могу кнезовати к'о што су ми стари кнезовали, нећу да будем ни турски алабаш!“ (исто: 321 ); „Нијесам ја вукарин Реља! Ја сам краљ брез краљевине... цар брез царевине!“ (исто: 328); „Кроз кратко вријеме, ја не био ко сам, ако се у Раткову чардак не забијели!“ (исто: 374 ); „Ми смо ти, што 'но веле, незаробљено робље једно: код куће а без куће, код земље а без земље, код постојбине а

3 Кочић има у виду становника Босне а не етникум. У предметном случају односи се на јазавца штеточину. На симболичком нивоу значајније је увођење „носа“, гогољевског мотива маске, чије пародијске прераде су присутне и у различитим делима Фјодора Михаиловича Достојевског. У овој паремији код нашег писца присутна су три семантичка нивоа: 1) реална слика, 2) наизглед колоквијална поспрдица са становником Босне и 3) мисаони велеобрт у значењу: мислите, туђини, да смо толико блесави „да пасемо траву“. 
без постојбине. Ми свијетла дана немамо, ми мирне ноћи немамо!“ (исто: 392).

Кочић је врстан познавалац етнологије и фолклористике свога краја, није без разлога од најпознатијих научних ауторитета свога времена позиван да се мане бесплодне а захтевне политичке активности и да се прихвати научног и књижевног рада. Поједине приповетке заправо су настале са намером да се сачини етнографски запис (Змијате). У њима су веома суптилно уграђени делови народне лирике и епике, увек у функцији сижеа иако су често верно пренети из народног књижевног израза, премда постоје и такви облици који су преобликовани изрази усменог стваралаштва, чак и са супротним значењем у односу на изворне. Може се претпоставити да су и такви, супротни, искази напоредо постојали у Кочићевој средини, што овде није од великог значаја, јер овом приликом не вршимо фолклористички попис већ установљавамо њихову генеалогију у Кочићевом књижевном свету. Присуство истих или сличних семема и митологема, односно, слика и мотива из метафизичког света, као и односа бића, реалних и митских, од исте су струке у српској народној усменој књижевности и у говору Кочићевих књижевних јунака. Поентирајући о лепоти сеоске девојке Тубе у истоименој причи писац ће друго поглавље завршитити паремијом: „'Савила би по небу облаке, делај не би по земљи јунаке!““ (исто: 20), чиме недвосмислено указује да порекло наведеног облика није изворно његово, ауторско. Оно би несумњиво могло да буде из неке збирке усмених облика која је писцу била позната, мање је вероватно да је само из говора његових савременика јер мноштво таквих примера није стављао под знаке навођења. Но, да је то аутентичан израз чије је порекло у српској духовној стварности препознаје се такође у поенти песме Срйска gјевојка из прве књиге Вукових Срйских нароgних йјесама, при чему се показује 
и истоветност функције паремије у структури два различита књижевна текста. Овај пример из Тубе представља узоран пример паремије која има особине народног усменог песништва: „Највећи број пословица је или у стиху, старијем тоничком и новијем акценатско-силабичком, или у ритмичкој прози.“ (Латковић 1987: 209). И пример из приповетке и овај из народне песме у Вуковој збирци имају све особине стиха српске усмене лирике, реч је о лирском десетерцу са три до четири снажна акценатска удара на алитеризованим слоговима и са обавезном цезуром, за такву врсту песме, иза четвртог слога:

$$
\begin{aligned}
& \text { „Нит' сам луда, нит’ одвише мудра, } \\
& \text { нит сам вила - да збијам облаке, } \\
& \text { већ ђевојка - да гледам преда се.“ } \\
& \text { (Караџић 1975б: 305) }
\end{aligned}
$$

Такве паремије, па и ова из Тубе, углавном и јесу настајале у десетерачкој поезији, најчешће би се „осамосталиле“ и изговарале у пригодним реалним ситуацијама када је порука из њих одражавала верну слику актуелног догађаја или упућивала на решење неке животне антиномије. То је и разумљиво јер десетерац има одређени реторички потенцијал какав у другим врстама народног стиха није у тој мери изражен. Ипак, код Кочића проналазимо у многим приповеткама и тачно наведене стихове из народног песништва, лирског и епског, које певају или изговарају одређени јунаци. Веома често кроз дивљење наратора или актера приповетке који слуша песму изражен је пишчев однос према усменој традицији. Сви ти стихови, очигледно из фолклорне заоставштине, нису паремијске природе, нити свима знамо порекло, навешћемо неке који јесу и којима се може установити извор. Петру Кочићу је извесно била позната збирка Народне йјесме Мухамеgоваца у Босни и Хериеіовини, 
издата 1888. године у Сарајеву, које је „сабрао Коста Херман, савјетник земаљске владе за Босну и Херцеговину“.

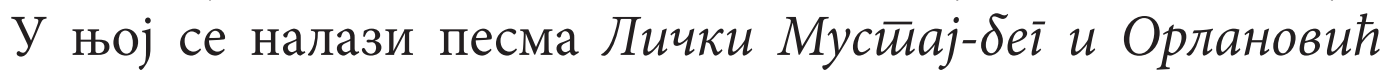
Myjo (3аїорје), ${ }^{4}$ где последњем 1650. стиху: „nigda b’jela dana za odmorka“ претходи дистих који је употребио наш писац у приповеци (Херман 1976: 294). Кочић ове стихове наводи у тренутку када драматичношћу врхуни прича Милића Вујиновића тако што изоставља последњи стих којим се завршава песма из Херманове збирке, који са̂м представља још једну паремију. И његов саговорник сведочи о познатости те песме, речима које описују доба на које се односе стихови:

„Кад је одузета кнезу Вукобраду суданија, он убрзо пресвисну од жалости, а на Змијању настаде вријеме, тешко и мучно вријеме, дјецо, онако вријеме што се у пјесни спомиње:

С крви ручак, а с крви вечера,

Свак крваве жваће залогаје“

(Кочић [1932]: 371)

4 Фототипско издање збирке Косте Хермана из 1888. и 1889. године приредила је Ђенана Бутуровић под насловом Нароgне йјесме Муслимана у Босни и Херцеіовини у еgицији Културно насљеђе Босне и Херцеговине (књ. 1-2, Сарајево: Свјетлост, 1976). Ова песма је под редном ознаком XXI у првој књизи, с. 253-294. Научне коректности ради, непосредно пре неголи сам уочио стихове из

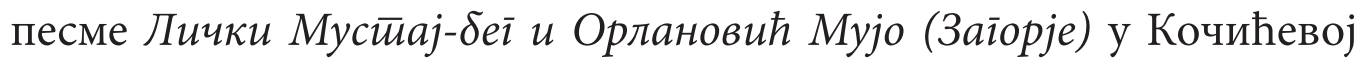
причи Змијане, Саша Кнежевић, фолклориста са Филозофског факултета из Источног Сарајева, у једном неформалном разговору скренуо ми је пажњу на очигледан издавачки и научни фалсификат Ђенане Бутуровић, као и на неке злоупотребе Петрановићеве збирке од стране Новака Килибарде. У време реиздавања Хермановог издања муслимани су у Југославији били политички признати за народ (Муслимани), а под појмом мухамедовци (мухамеданци) и даље се подразумевала верска припадност, као што је то увек било, па и у доба састављања збирке Косте Хермана. 
Крајишка епска поезија, како то каже Алојз Шмаус позивајући се на Муркова истраживања, јасно се дели на две подврсте, различитих формалних и извођачких својстава - она која се изводила уз гусле и у свему је подударна тзв. јужном, херцеїовачком типу и друга која се изводила уз тамбуру тзв. крајински тип (Шмаус 1966: 271). Стихови из ове збирке народних песама, односно из Кочићеве приче, као и са̂м епски свет Кочићевог књижевног дела, као и његова идеологија, припадају јужном типу и природан су ток развоја усмених узора у ауторској књижевности. Писац се послужио оним делом паремијског исказа из епске песме из разлога што се ослонио на опис прилика из тога времена које је у Доgайку на крају прве књиге дао Коста Херман наводећи историјске и фолклорне чињенице о мухамедовцима који се помињу у збирци. На самом крају прве књиге састављач је посветио простор песмама о браћи Хрњици и Хрњчићима. Након описа опште метежности у Крајини, о којима у 3мијағу приповеда и Милић Вујиновић, где су мухамедовци и православни помешано војевали свако против свих, ${ }^{5}$ у Хермановом Доgайку ће то опште расуло и крвопролиће бити закључено завршним стиховима песме:

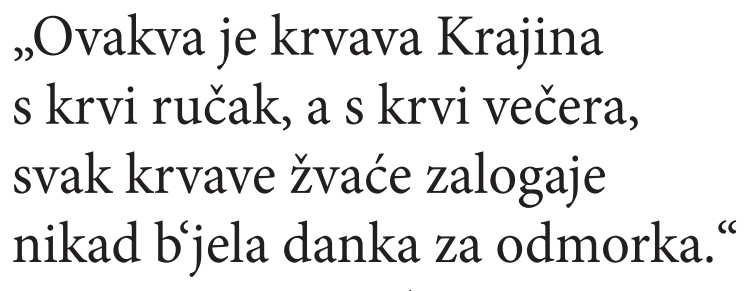

(Херман 1976: 608)

Као што се види, реч је о канонизованом паремијском облику који се користио једнако међу припадницима

Амбивалентно схватање савезника и ратних противника код потурчењака у Крајини уочљиво је на примерима њихових најзнаменитијих епских јунака попут Будалине Талета. Оно је увек усмерено првенствено према етичком (Крњевић 1980: 215-216). 
православне и мухамеданске заједнице, за којим је посегнуо и Коста Херман, када је требало да се представи сурови карактер Крајине. Вероватно је у народном говору, као општа жеља, настао и овој пословици антиподан говорни израз „мирна Крајина“ (Кочић [1932]: 273). Аутохтоност књижевног света Петра Кочића препознатљива је једнако из књишких и из усмених примера које смо навели, али треба нагласити да паремијски принцип у стваралаштву овога писца, преузет из народне свести, има особине тог принципа и када књижевнојезички израз не достиже коначну форму паремијскога облика, што због одсуства експлицитно исказаног поређења или паралелизма, што због недовољне метафоричке или симболичке фигуративности. Тај процес згушњавања мисли је својеврсна дијалектика живог знања које има сталну тенденцију апсолутизовања искуства. У Кочићевим прозама постоје примери таквог народносног закључивања којима се судови о животу преводе у један органон колективног знања, те се сусрећу на различитим степенима паремијске оформљености:

„Лијепи задрушки мир, ред и поредак владао је под кровом његова дома. Свако је чељаде знало свој посао, па је радило без поговора, с вољом и увјерењем да себи ради. Лијепи стари задрушки животе, како те брзо нестаде.“ (Кочић 19??: 18)

Исто то, градативним јововским ${ }^{6}$ реторским питањима:

„Зар нијесам пис'о на намастире и цркве; зар нијесам дав’о кљасту и сакату; зар нијесам славио име твоје и прислужив’о свијеће слави твојој?....” (исто: 326)

6 Уп. Матић 2002: 314. 


\section{Структурно учешће паремије у Кочићевом књижевном свету}

Места у тексту где сусрећемо паремије у Кочићевим приповеткама и у Јазавиу йреg суgом говоре о њиховом ванредном статусу у творењу књижевне стварности. Оне се редовно налазе у приликама када на крају приповедних целина треба да се поентира згуснутом мишљу или у тренуцима када кулминира неспоразум или треба подзидати у дијалогу изложени став. У циљу говорничке уверљивости и веродостојности света готово увек су присутни говорни изрази и изреке који аутентично припадају реалном простору одабраном за књижевну твар дела. Пословички облици су употребљени у дихотомијским дијалошким случајевима - између актера који лако разумевају и оперишу таквим облицима и оних код којих овакве форме израза изазивају упитаност, недоумице и збуњеност. Основна функција паремија је истакнута, пре свега, у изразитој сликовитости и поетској сублимности језика, што представља његов нарочити функционални ексклузивитет; оне се по језику диференцирају, односно, истичу у односу на прозни миље у којем се налазе. Како су уобичајено рефлексивни сажетак анегдотских прича, а иначе реткост у већим приповедним усменим врстама, компоноване у облику не само семантичког него и синтаксичког и фонолошког паралелизма, књижевном изразу Кочићевог дела придодају квалитете поетско-есејистичког. Са пословицама се, иначе у одређеним приликама, могу поистоветити и други краћи облици усменог стваралаштва, попут питалица, када су испуњени услови поетског израза, пре свега када су стилски на завидном нивоу фигуративности. Нарочита присутност и књижевна вредност употребљених паремија у приповеткама Петра Кочића и у драми Јазаваu, uppeg суgом, ьегов језик чини засићеним лирским изразом и сведеним мисаоним 
исказима блиским општим истинама којима се постиже онтолошка вертикала књижевног света. Међутим, појам „стилизације“, који је навео Герхард Геземан уз „експресионизам“, као један од најважнијих за објашњење света епског дела, говори у прилог паремије као надисторијске истине: „„пром(и)јенио свијетом“ (Кочић [1932]: 18, 366); „Је ли мени изиш'о ђогат (бијела 'позовка') за потрицу?“ (исто: 25); „Знамо и ми макар што је славно ак' и не знамо шта је масно.“ (исто: 26); „Оде ти тај к’о амин!“ (исто: 28); „оде под црну земљу“ (исто: 29); „Зна вала, ђе је небо кукама приковано“ (исто: 30); „очи му заокружиле као кози пред мрак“ (исто); „Ман’те се, људи, ћорава посла!“ (исто: 32); „Сад ће те двије године протећи к’о ладна вода“ (исто: 39); „подапела губице, к’о цигански бубањ“ (исто: 41); „не иште ми ниђе срце“ (исто: 42); „Немој ти, кнеже, знаш, нада мном трти рокве“ (исто: 44); „Код ње иде све к’о на тетиво.“ (исто: 45); „наша је ноћ и божја“ (исто: 82); „Млога је мајка ш ње закукала“ (исто: 127); „Што си посрљ’о ко прасе у сурутку? (исто: 166); „А, у мој сирац!“ (исто: 194); „није пукло, већ је никло“ (исто: 196); „Заклијештио очима ко коза пред мрак“ (исто: 237); „А, шејтане напријед ти се пете окренуле“ (исто: 246); „Ако се ја почнем шалити, биће меса орлу и гаврану“ (исто: 247); „Откако је гавран поцрнио“ (исто: 251); „И мртва уста на смијех натјерале“ (исто: 262); „Што ућиних од себе, слип ходио по дунајлуку!“ (исто: 264); „Убрзо ће завришћати ћорав ђогат под ћоравим Османом..." (исто:

7 „Епика тражи неку вишу истину, која се понекад не може приказати без преиначења чак и добро познатих факата. У епици стилизује се не само песма него и живот као такав. Стилизација се не ограничава појединим песничким детаљима, него је у основу епског стварања уопште. Питање да ли епика тачно приказује историјске факте не одговара суштини ове уметности; тачније би било питати да ли историја пружа факте које епика може да прикаже 'како је било.“' (Браун 1966: 391) 
265); „И прва се носила кренуше из Рељине куће.“ (исто: 324); „Док једном не смркне, не море другом сванути.“ (исто: 325); „Чудне ли среће и црна ли удеса мога!“ (исто: 326); „Кад нешто једном пође, не заустави се!“ (исто: 328); „са звијездом, што 'но веле, падам, са звијездом устајем“ (исто: 339); „све је без Тебе ништа - ништа је с тобом све!“" (исто: 393).

Стилизованост или поетски призвук паремијских облика у Кочићевим приповеткама и драми има многе особине народног усменог исказа, па ипак је њихова употреба унутар дела неупоредиво комплекснија од несумњиво великог изворног књижевног потенцијала. Овај писац, уз Бору Станковића, али из сасвим других разлога, представља најлиричнијег прозаисту епохе у српској књижевности којој је припадао. Свет његовог књижевног дела обележен је значајним уделом импресионизма, афективног доживљаја, но то није постигнуто само иманентним учешћем специфичног садржаја за који је писац судбински био везан и заинтересован, него и његовим песничким талентом који је оставио траг више у прозним остварењима. Осим што је паремија по књижевностилским особинама изнад прозног излагања, код Кочића је сусрећемо у ситуацијама вишекратног понављања, као у поетском говору, када аутор настоји што вернијој карактеризацији лика. Желећи да што јасније прикаже природу проводаџике Каласуре, „(неки је зову и Летикујом)“, која долази да наговара Тубине родитеље да удају кћер за Лазара Мајсторовића, писац чак и музичко-ритмичким понављањима истих или сасвим сличних облика дочарава њен магијски говор. Тако ће на кратком простору два пута употребити сличну паремијску формулацију, на почетку: „Они држе жене к’о мало воде на длану“ и на крају: „Мајсторовићи пазе жене к’о мало воде на длану!“ Уочљиво је да је суштинска лексичка разлика између ова два готово једнака исказа у глаголима „држе“ 
и „пазе“, што је веома значајно за њихово разумевање у културном простору (Кочић [1932]: 42) Глагол „држати“ у овој културној средини се уобичајено употребљава када постоји намера да се саопшти реалија о поседовању стоке, живине, у најбољем случају служинчади, док „пазити некога“ изражава поштовање према ономе ко је предмет пажње и уважавања. Не може се сматрати случајним овакав редослед паремијских конструкција којем је на овоме месту прибегао писац. У истом одсечку ове приче, у магијском солилоквију Летикује, три пута he се поновити елиптична паремија која је неупоредива по музичко-ритмичким особинама поетског израза - на почетку, у средини и на крају говора: „близу вода, близу дрво, близу млин!“ (Кочић [1932]: 42). У првом случају она се налази у истој реченици као опис иза нетом објашњеног облика како Мајсторовићи „држе жене“, након синтагме између њих „а јопе’ [...]“. У средини Летикујиног говора конструкција „близу вода, близу дрво, близу млин“на путу је осамостаљења, али још увек у атрибутској улози, иако је синтаксички прерасла синтагму, иза две краће реченице о статусу куће Мајсторовића: „Своја земља, сестро! Мало је данас так'ијех. [...]“ (Кочић [1932]: 42). На крају проводаџијске бајалице два паремијска исказа мењају и ред навођења и номинални значај, она прва о „пажењу“ жена у Мајсторовића добија описну, секундарну улогу, а ритмичко-музичка емфаза „близу вода, близу дрво, близу млин“ се номинује испред ње. Понављање целих паремијских исказа у структури књижевног текста, као што се види из ових Кочићевих примера, има значајан стилогени удео, али и понављања лексема у њима самима на високом стилском нивоу организује значење: „пушка ми, пушка ти“ (Кочић [1932]: 254). И у другој причи која говори о несрећној љубавној судбини двоје младих приповедач израста из лирског народног наслеђа, из поетских паремија он ствара атмосферу, заплет, слику, мотиве и друге 
елементе приповедне форме. Бежећи уочи саме свадбе Марушка закључује своју и судбину приче: „Прије и у гору и у воду него натраг! Волим да ме бијесни вуци на комаде истргају, него да ме се његова рука дотакне! (Кочић [1932]: 143-144). ${ }^{8}$

Осим музичких особина својственим лирском тексту која на семантичком плану додатно конфигуришу Кочићев књижевни свет, и у његовим епским размерама узастопна употреба израза има својеврсну функцију. Један од централних карактера његовог персонажа је Симеун Ђак из манастира Гомјеница; (анти)херојски лик подржан је народном изреком која се јавља у приповедачком петокњижју о његовим подвизима. Када учествовањем других у догађајима и у његовој самохвали почне да бива ретардиран измаштани херојски лик, он коригује контекст приче али и слушалаца строгом изреком: „Буди мене миран!“ (Кочић [1932]: 97). У првом случају реални хијерархијски ауторитет игумана Партеније устукнуће пред књижевним ауторитетом епског Симеуна Ђака, што је изражено два пута поновљеним „буди мене миран“у тренуцима када игуман жели да га посаветује уочи јуначких подвига. У другој приповеци о овоме књижевном јунаку, због ометања излагања о његовим подвизима, присутни ће поскочити и смирити га да не застрани у ту страшну изреку. „Једва га умирише и свладаше да не подврисне: „Стој! Буди мене миран!“ (Кочић [1932]: 202). Њоме се, након што су присуством хумора и фикције доведени у питање Симеунови „подвизи“, наизменично успоставља његов херојски лик.

8 УП. „'Не дај мене, мајко, за недрага!

Волим с драгим по гори одити, глог зобати, с листа воду пити, студен камен под главу метати, нег' с недрагим по двору шетати, шећер јести у свили спавати.““ (Караџић 19756: 165-166) 
Овај књижевни јунак, уз Давида Штрпца, у односу на све остале неупоредив је у Кочићевом књижевном свету, и један и други представљају изграђене типове крајишког сељака, одрживог на више степеника функционисања тог света. На првом пониженост и поробљеност Крајишника од две монархије које се смењују у улози окупатора добија један сасвим реалистичан приказ у делу овога писца, други је ниво њихово прибегавање смеху и сатири, када треба и аутоиронији, који се постиже како урођеним етно-психолошким особинама тако и пишчевим вештим излагањем, док је кровни слој, који је израз највеће егзистенцијалне озбиљности, постигнут ствараочевим дубоким познавањем културног текста који је захваћен у прозама. Тако истовремено Симеун Ђак изгледа као један безначајни фантаста, смешна људска појава и пророк народног вековног сна о слободи, и у томе нема никаквог каузалистичког антагонизма, као ни у тумачењу изреке „Ракијо мајко“ на којој се заснива његово постојање, што је и наслов једне целине о Симеуну Ђаку (Кочић [1932]: 221). Осим што изрека собом носи увек и буквално значење, универзалном применљивошћу на све могуће ситуације суштинско је њено фигуративно значење. Ракија је овде главни покретач,

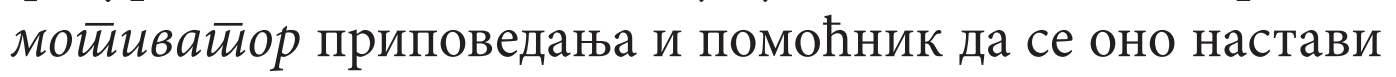
када год прича у грлу почне да запиње. Поред тога што ова прича има озбиљно уткану идеологију, она је споља гледано један крајње објективан фолклористички запис о начинима настанка и записивања усмених приповедних облика. По томе неодољиво подсећа на речи Вука Ст. Караџића о методу којим је мотивисао Старца Милију док му овај није некако казао четири веома значајне песме наше епике; у Кочићевој причи ракија из језичког израза има сасвим супротну улогу, за разлику од њене амбивалентне функције код Старца Милије - да покреће а потом уништава говорење песме, у причи нашег писца 
она се појављује као дозирана помоћница на местима где долази до застоја у причи, тј. машти у којој прича настаје. Писац је и у приказивању најдоступнијег, реалистичног слоја врхунски приповедач који поставља главна питања о поузданости приче. Када Симеуна Ђака понесе аутосугестија о његовим подвизима, тај фантаста заборавља на реалне чињенице о радњи смештеној у време пре изласка сунца, коју такође излаже у комбинацији неколиких говорних израза: „'Људи, нећете ми вјеровати, а ово је цијела цјелцата истина: кад се огледа' на шјену - ни узми, ни подај - права правцата швапска генералина!' 'Е, људи да и то чујем, док нијесам умро: шјен брез сунца!' чу се неко иза каце.“ (Кочић [1932]: 85). „Неко иза каце“ је сасвим оригинално стајалиште посматрача у причи, Кочић је први осмислио и именовао бивство неодређеном заменицом, заклоњено иза каце (двострука онтолошка негација), у којој је сировина из које ће потећи ракија и која пространство слушалаца и простор приче реално-имагинарно уједињује. У наведеном примеру „неко иза каце“ је једини пажљив посматрач у причи, а већ на крају Зулума Симеуна Бака и његова пажња биће поробљена Симеуновом фантазијом, опет казано паремијском конструкцијом: „'Људи моји, нит је так'ије' јунака кад било, а какав је вакат наст'о тешко да и’ буде!' чуди се и крсти онај за кацом.“ (Кочић [1932]: 89). Једно неодређено у „Неко“ у току приче прераста у опште „Онај“. „Онај иза каце“ је ма ко или било ко од њих, заправо, сви они заједно када нису личним именом и презименом означени, трезвеност и опијеност су два пола „онога иза каце“, које зависе од свима заједничког наратива. А тај наратив је други степеник на семантичким стубама у причама о Симеуну Ђаку, он мора да буде установљен у парадигматичном епском десетерцу, прво у афективном слоју њиховог доживљаја реалног света, а у руху народне изреке: 
„Већ је крвца из земље проврела,

Земан дош’о, ваља војевати.“ (Кочић [1932]: 94)

Онтолошка лествица Симеуновог фантастичног света, и на нивоу реалног догађаја и на нивоу душевног доживљаја, задобија ауторитет не толико у способности измишљања причаоца колико у ослонцима тога бивства, а они су редовно повезани са историјским чињеницама који су дотерани према Симеуновим фантазијама, учешћем, у време причања, већ умрлога игумана Партеније: „Ено му гроба, нек ми не да лагати“ (Кочић [1932]: 83); „Покојни Партенија - и у гробу му 'вала“ (Кочић [1932]: 206); „јер се ова земља научила мијењати господаре као Циганин коње“ (Кочић [1932]: 225); „Људи не били, већ курве и роспије, ако га не окајали“ (Кочић [1932]: 244). Иако је најважнији подстицај обама тим нивоима причи поред казана и успаљености душевнога бића, наизглед лакрдијашкој сцени, ракија је симболички меритум духовнога простора у којем се прича остварује. Кочић је на почетку приче Ракијо мајко, преко Симеуна, подсетио слушаоце код казана и читаоца о њеном значају у свим иницијацијским обредима српскога народа: „Ракија свађе и увијек треба: и на дому и на збору, и у весељу и у жалости. Без ње не мореш ни крстити, ни запросити ни испросити, ни вјенчати ни сахранити.“ (Кочић [1932]: 221). Овај паремијски конструкт он умешно надовезује анегдотом о „нашој православној Русији“ и руском цару: „Сами цар светога православија, цар над царевима, попије сваки дан, не лажем ти већ тако у књигама стоји, по пет шест ока вотике." (Кочић [1932]: 222). Псеудобиблиофилски податак се даље наставља у хумористичкој надоградњи и показује да чланковита синтаксостилистика паремија пружа готово неограничене могућности надограђивања приче уколико је реч о стилски обојеним додацима, па и такве који смешно претварају у озбиљно, 
и обрнуто, или истовременог присуства оба ефекта на различитим нивоима. На појединим местима у причи ликови се у дијалогу споразумевају готово само паремијским облицима: „узвртио се Исаија к'о Циганин у котлу“ (Кочић [1932]:205); „Немаш дјеце, па да ће, ако вечерас погинеш, плакати гладна и гола за тобом“ (Кочић [1932]); „Глава, болан, игра“ (Кочић [1932]); „Тешко оном кога други брани“ (Кочић [1932]); „И стари су ти бјежали кукавицо сиња!“ (Кочић [1932]); „Нек је отац Сопронија задовољан и почествован, а за ме је лако“ (Кочић [1932]). Укупно бивство догађаја, реално, историјско, фантастично, душевно и духовно, натопљено је ракијом: „Ракијо мајко! Ракијо, и отац и мајко, помози сад или никад!“ (Кочић [1932]: 238); „Капетан прима једно по једно поштење“ (Кочић [1932]: 253); „Ракијо, ракијо, свађе ли си од помоћи и користи, дрво ти се посветило, да Бог да!“ (Кочић [1932]).

Многоструке су и неодвојиве везе Кочићевог ткања књижевне структуре са народном књижевном традицијом, Симеун Ђак је парадигматски послетак књижевног Краљевића Марка; оно што га комплетира као највећег епског јунака, појава Симеуновог 'ата огледа се у Марковом Шарцу. Сви велики епски јунаци грађени су у седлу, али само су Марко и Симеун Ђак са својим седланицима запајали се вином или ракијом. Две су важне етапе у творењу слике његовог коња, Симеун Ђак ће је започети поређењима: „Вришти 'ат пода мном, баца пјену, пропиње се на предње ноге, а испод њег' сијевају варнице к’о небеске свјетлице.“ (Кочић [1932]: 211). Фигуром поређења се, ипак, не може установити самостално бивство без наслањања на нешто уверљивије, стога приповедач, и са̂м уверен у неуверљивост реченог, прибегава накнадном прибављању ауторитета довршавањем слике у провербијалној форми: „А кад пирне и вркне кроз ноздрве - море бити, да ми нећете вјеровати 
- а кад пирне и вркне кроз ноздрве, са дрвећа полијеће лишће.“ (Кочић [1932]: 211-212). Успостављањем ликова у традицији усменог песништва структурирају се микросижеи из препознатљивих паремијских облика народног епа у Симеуновом приповедању: „Курво кучко, Симеуне Ђаче! Курво кучко, Парто калуђере! Јесте ли ми конак приправили? [...] Курво кучко, Асан-беже Чеко, у сусрет ти иде Симеуне!“ (Кочић [1932]: 211). ${ }^{9}$ Међутим, да ма која пропаст не зависи искључиво од онога који је насупрот него и од свести о самом себи говори библијски мотив о „проклетству и осуди земље на пропаст због људских грехова и безакоња“ (Пешић, Милошевић - Ђорђевић 2011: 207), навођен у већем броју српских усмених народних облика као и код Кочића: „Пошљедње је вријеме настало“ (Кочић [1932]: 203).

Књижевне слике и мотиви који су постигнути паремијом представљају најекспресивнији слој књижевног дела, тога ради што су то изрази који теже апсолутној вредности, они не настоје да буду само логични него и онтологични, поготово када су парадоксални: „Лани нас уби кља, ове године оби град, а до године нек' нам царевина пошље добра десетара - па никад боље среће!“ (Кочић [1932]: 107); „'Зар да нам, што 'но онај не'кав говорио, јучерашњи најменик буде кнез!' 'Зар да нам јучерашње вузле заповиједа?!' издера се један.' 'Ја знам кад му је мати

9 Уп. „Ал' говори Мандушићу Вуче: 'Курво, кучко, сењски капетане““ (Караџић 1975в: 280). Исти канонизовани облик срећемо и у лирској песми „Очи соколове и ђаволове“: „Курво, кучко, лијепа дјевојко“ (Караџић 19756: 265). Увредљивој врсти припада и она којом Ага од Рибника позива Ђурђа Сенковића на мегдан или на покорност, где је афективни слој, закључком разобличене паремије, главни покретач сижеа: „,... ако л', Ђурђу, на мејдана нећеш,/ преди мени гаће и кошуљу, нек ја знадем да си ми покоран.“” (Караџић 1975в: 259). Лик Симеуна Ђака акционално коинцидира са осветником Ивом Сенковићем, са чиме су сагласна и симболичка подударања вечитога ђака и голобрадога детета. 
цуром била!' додаде други. 'Мани се, чоче! Ја знам кад га Бог није ни мислио створити!'“ (Кочић [1932]: 130); „да се почем турски земан поврати, она би могла са својом памети насред Бања Луке кадија бити“ (Кочић [1932]: 168); „Болан, болан, ја би' крви своје, иако је снажна и отровна к’о змиски ујед, уточио нашој премилостивој Земљаној влади...“ (Кочић [1932]: 194); „То су планинци моји, који кажу да жене и кукавице шапћу.“ (Кочић [1932]: 336); „Они се ни Богу не умеју тихо и полако молити.“ (Кочић [1932]). Ти згуснути народни изрази се редовно појављују у неком или у више облика паралелизама, на синтаксичком, семантичком и фонолошком плану: „Зар ја четрдесет гради будаласт?! О млого, по Богу браћо! Па колико сте онда ви?“ (Кочић [1932]: 197); „Мој вермане, мој златни земане.“ (Кочић [1932]: 297). Паралелизам тако постаје главним градивним својством паремијског принципа, упоредивошћу два или више члана који га чине, иако синтаксички фигура поређење није адекватна овом облику. И када долази до проширења паремије при настанку већих приповедачких целина, те је њено идентификовање заклоњено додатим слојевима, присуство паралелизма ма на којем нивоу подсећа да је у основи целог дела у почетку била паремија. У том погледу добар пример је приповетка Илица 'Ogалица и Лазица Вуиялица као једна врста реинтерпретације усменог наслеђа о трикстеру Ери. Мотив преваре је установљен на паралелизму два непомирљива света, две супротне свести - оне домородачке народне, која је непосредно-интуитива, и оне дошљачке окупаторске, која је каузална, рационално-апстрактна. (Кочић [1932]: 295-299) У тој краткој пародичној причи паремијски принцип је проведен од најнижег слоја карневализованог вашарскога дијалога, преко композиције тематско-мотивског слоја, до философског сучељавања света и несвета, сублимираног у бивству јунака по којима је прича и названа: „Друкчије 
се они зову код 'котарског уреда као суда'. То свијет не зна, па не знам ни ја.“ (Кочић [1932]: 296). Речца „као“ и друга реченица овога цитата, која следи иза номиналног небивства и провербијална је, идентитете двају различитих светова одређује реалноисторијски и у вечности.

Паралелизам и када суштински у себи носи провербијалне одлике на формалном плану их увек не показује, на то упућује један пример у консензусу који Давид Штрбац настоји у два наврата да постигне са Суцем, кобајаги нудећи поверљиве информације о анархичности српских народних првака: „Е, оћете ли осудити овог јолпаза, па ћу вам казати?“ (Кочић [1932]:183). И у овом случају, где паремија није сасвим уобличена али се наслућује њен семантички слој, и у случају Илице 'Одалице, када метонимијски преусмерава причу од шаљивог омотача ка озбиљној суштини, у најбољој традицији усменог и ренесансног приповедања, сиже је одређен паремијским садржајем: „Ја сам и тежи и дебљи од оног његовог човјека, јер мене ни царски кантар не море поднијети! (Кочић [1932]: 298). Оно што се на најнижем нивоу нетачно тврди на вишем нивоу се парадоксално потврђује, што јесте важна особина усменог приповедања, које је под апофатичким кровом развило нијансиране фигуре где се негацијом, порицањем, изостављањем и сл. потврђује баш оно што се одриче. Паремије које у себи садрже негацију, чиме се најчешће аминује управо оно што се одриче, нарочито су моћне на семантичком, а тиме и на идејном плану књижевног дела: „Зове се: Ни Давияова, ни иарска, ни сйа’иска.“ (Кочић [1932]: 173); „Да сам ја луд, ја би’ био у лудој кући, а не би се данас разговар'о с царским људима.“ (Кочић [1932]: 177); „невјенчана је, прошћеш, жена и слађа и дража од вјенчане“ (Кочић [1932]: 180); „Да је икакве вјере, не би дир'о у моју сиротињу.“ (Кочић [1932]: 188); „Е, моје дијете, да је ово наш цар, ја би’ од радости заплак'о.“ (Кочић [1932]: 195); „До душе, што свијет, веле, говори ил’ је било ил' ће бити. Није нешто брез ништа!“ (Кочић [1932]: 364). 
Наведени примери показују низ различитих морфостилистичких примера којима су оцртани високи домети Кочићевог књижевног стила, а сви су начињени одређеним одрицањем по паремијском принципу усмене традиције, гдекоји и позивањем на њу. Значајни делови текста који одражавају пишчев идејни слој, а непаремијског су садржаја, засновани су, исто тако, на истицању негације. Структурно и идејно у Јазавиу йреg суgом остварују се генеалошки у стилу народног израза који овај писац развија, по слободи, у свим могућим књижевним функцијама, те тако остварује и драмску радњу. У сценско време (Виготски 1975: 226) једног судског рочишта стаје судбина Давидова и његове породице, а у њих фатум народа и земље. Није наодмет рећи да овај својеврсни Давидов паримејник представља Кочићеву књигу псалама којом дочекује неког свог Соломона и извесно верује у помазаника из својега рода.

O (не)могућности закључка

Паремије су у Кочићевим приповеткама и у Јазавиу ūpeg суgом иманентни део пространства које је обухваћено у њиховом књижевном простору, оне су есенција његовог постојања, и код овога ствараоца се појављују у пуном обиму функционисања унутар и ван приповедног дела. Догађаји којима се остварује њихово бивство изван апстрактне језичке конструкције доказују колико их је немогуће подредити општим концептима књижевне структуре. У Кочићево приповедачко дело улазе као опште обележје културног простора којим је означен његов књижевни свет, и колико је више осетна та искуственост, тиме су оне живље а дефиниције немоћније. Установљење особитог књижевног света који израста из непосредног искуства ослоњено је на реалне догађаје, али су у његовом књижевном делу постигнути поступком стилизације, где је 
формална историја ускраћена пред епском сликом јер не поседује такав ниво веродостојности као књижевни свет.

Паремије се срећу у разноврсним улогама на микро и макроплану структуре његовог остварења. Пре свега у експозицији сликовитости и сублимности у односу на приповедни текст у којем се налазе. Изразитог су поетско-есејистичког квалитета, што истиче њихов степен изображености на нивоу мисли и на нивоу речи. Таква засићеност лирским изразом и апсолутизованост опште животне мудрости граде онтолошку лествицу Кочићевог књижевног света. Стилска употреба паремије понављањем унутар ње или као целине унутар једног приповедања, по принципу компоновања лирске структуре, у донекле измењеним морфолошким ситуацијама књижевног текста одређује је као кључни фактор семантике тога текста. Она, даље, има истоветну корективну улогу и на односе унутар књижевног дела и на слушалачки контекст пред којим се приповеда. Изрека је код Кочића у средишту у свим видовима: као мотиватор, фолклорно-књижевни амбијент, књижевна слика, тематско-мотивски оквир, идејни слој и др. Чланковита синтаксостилистика паремијске конструкције пружа готово неограничене могућности надоградње и овај писац их користи усмеравајући приповедање час у смешном час у озбиљном смеру или истовремено постижући оба ефекта, при томе остварујући највишу духовну стварност књижевног дела. Истим језичким средствима, у духу усмене традиције, путем парадигматских ликова твори епске карактере и у њима развија мрежу сижеа својих приповедака. На основама паралелизма, који је иманентан паремијама, код Кочића се види како спољашња стилска особина поређења постаје главним унутрашњим односом, премда је синтаксички фигура поређења у односу на метафору, метонимију, антитезу, симбол и др. у најкраћим књижевним формама мање подесна од побројаних. 
У духу народне књижевне традиције одрицањем, односно, фигурама негације успоставља се највиши степеник бивства књижевног света код овога приповедача, чије књижевно дело по свим карактеристикама представља северну границу guнарскоі̄ књижевног мишљења коју на југу затварају Стефан Митров Љубиша, Марко Миљанов и Анђелко Крстић. Одрицање и негација, и када су битна особина књижевног стила, не представљају модел агресивног културног и психичког типа него управо парадигматски изворно хришћанског одустајања од сотоне, отуда је и Симеун другим делом имена - Ђак паремизиран, тј. онај који учи цео живот. ${ }^{10}$ Дакле, пуца од кочићевског здравља.

\section{Извори}

Караџић 1975а: Караџић, Вук Стефановић. Срӣске нароgне йословице и gруіе различне као оне у обичај узетие ријечи. Београд: Нолит, 1975

Караџић 19756: Караџић, Вук Стефановић. Срӣске нароgне ијесме, книіа иррва. Београд: Нолит, 1975

10 „Као што је Бакоња фра Брне оличење нашег здравога примитивца у лукавоме католицизму, и у неку руку изобличење католицизма, тако је у мањим сразмерама, Симеун Ђак оличење нашега примитивца у дивљем православљу и мегданџиском србовању, којима изражава наличје.“ (Богдановић 2002: 23) / „Симеунов и Давидов оптимизам, који је уједно и Кочићев, пун је неустрашивог самопоуздања и надахнут је вером у нову, бољу отаџбину реда, самосвојности и истине. Овај оптимизам голих гладних врховаца савршено се разликује од оптимизма што долази од пуног стомака и уредне кесе и столице. Овај оптимизам потиче од оне божије искре, скривене у оном ситном најунутарњијем делићу наше душе, који је потпуно независан од стомака и физичког благостања. Он је у ствари израз духовне и душевне еуфорије, која се не стиче факултетским дипломама ни моралним ексерцирањем по напутку Игњација Лојоле.“ (Будимир 2002: 49) 
Караџић 1975в: Караџић, Вук Стефановић. Срйске нароgне йјесме, книїа йрећа. Београд: Нолит, 1975

Кочић, Петар. Целокуйна gела, кюиі̄a ӣрва. Београд: Народна просвета, 1932

Herman, Kosta. Narodne pjesme Muslimana u Bosni i Hercegovini [u prvom izdanju (1888): Narodne pjesme muhamedovaca u Bosni $i$ Hercegovini]. Sarajevo: Svjetlost, 1976

\section{Литература}

Богдановић, Милан. „Два лика Петра Кочића“. Јован Ивановић (прир.). Пейар Кочић у йаралелама. Бања Лука: Матица српска Републике Српске, 2002. 19-23.

Браун, Максимилијан. „Појам 'стилизације’ у народној епици“.

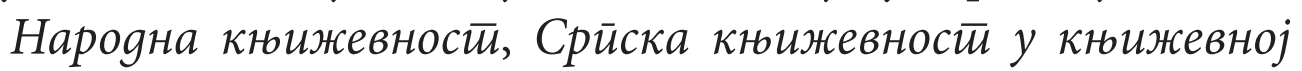
критичии II. Београд: Нолит, 1966. 391.

Будимир, Милан. „Кочићев месијанизам“. Јован Ивановић (прир.). Пейар Кочић у йаралелама. Бања Лука: Матица српска Републике Српске, 2002. 44-54.

Vigotski, Lav. Psihologija umetnosti. Beograd: Nolit, 1975

Živković, Dragiša (ur.). Rečnik književnih termina, drugo, dopunjeno izdanje. Beograd: Nolit, 1992

Зуковић, Љубомир. „Кочићев однос према усменој књижевности“. Јован Ивановић (прир.). Пейар Кочић у йаралелама. Бања Лука: Матица српска Републике Српске, 2002. 235-247.

Ивановић, Јован Н. Петиар Кочић у иаралелама, хрестоматија. Бања Лука: Матица српска Републике Српске, 2002

Јовановић, Јелена. Кюиїа сритских народних йословииа I, IV изgате, Сйудије срйске и словенске. Београд: Научно друштво за неговање и проучавање српског језика, 2006

Katičić, Radoslav. „Književnost i jezik“. Zdenko Škreb, Ante Stamać. Uvod u književnost, četvrto, poboljšano izdanje. Zagreb: Globus, 1986. 107-131.

Крњевић, Хатиџа. „Усмено казивање као књижевни поступак у Кочићевом циклусу о Симеуну Ђаку“. Живи йалимпсестии 
или о усменој ӣоезији. Београд: Нолит, 1980. 209-217.

Латковић, Видо. Нарояна књижевности, I, IV изgане. Београд: Научна књига, 1987

Матић, Светозар. „Петар Кочић и легенда о Јову“. Јован Ивановић (прир.). Петиар Кочић у йаралелама. Бања Лука: Матица српска Републике Српске, 2002. 311-316.

Милошевић-Ђорђевић, Нада: $O g$ бајке gо изреке (обликовағе и облиии срйске усмене йрозе), друго издане. Београд: Друштво за српски језик и књижевност, 2006

Петковић, Новица. Језик у књижевном делу. Београд: Нолит, 1975

Пешић, Радмила и Нада Милошевић-Ђорђевић. Нароgна кюижевности, речник. Крагујевац: Лира; Београд: Златна земља, 2011

Шмаус, Алојз. „Студије о крајинској поезији“. Нароgна кюи-

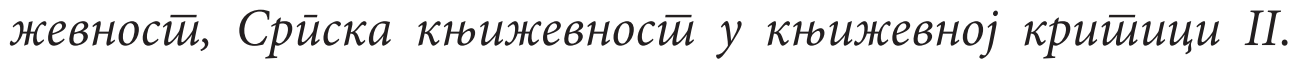
Београд: Нолит, 1966. 270-291.

Ненад Р. Кебара

\section{ГЕНЕАЛОГИЯ И ФУНКЦИЯ ПАРЕМИИ В ЛИТЕРАТУРНОМ МИРЕ П. КОЧИЧА}

\section{Резюме}

Кратчайшие формы литературного устного выражения: речевые формулы,поговорки и пословицы, называемые в литературоведении по-разному, рассматриваются в качестве уникального принципа создания, относящегося к паремиям. Невозможность общей значимости определениямы видим в двойственной природе паремии, состоящейся из языкового выражения и события, который ее воплощает в себе. Откуда проистекает и каким образом этот особый вид фольклорного мышления отражается на достоверности литературного 
мира,в то время какон является основной особенностью его творчества,в этой статье мы рассматриваем на примерах литературной работы Петра Кочича. Мы пришли к выводу, что существует своеобразный принцип паремии и что его действие может быть идентифицировано во многих элементах литературной структуры объемных работ, в чьем создании участвует.

Ключевые слова: паремия, литература, литературный мир, структура, стилизация 